\section{Placeboeffekten kan utnyttes bedre}

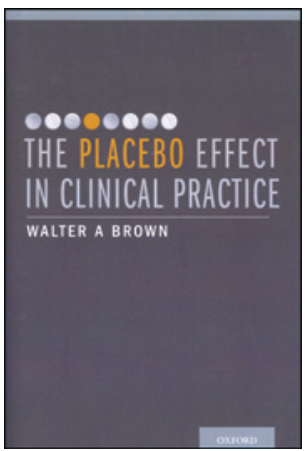

Walter A. Brown

The placebo effect in clinical practice

177 s. Oxford: Oxford University Press, 2013.

Pris GBP 30

ISBN 978-0-19-993385-3
Walter A. Brown er professor i psykiatri i Boston, og han har fra slutten av 80-årene vært (med)forfatter av drøyt 20 fagartikler om placebofenomenet, $i$ alt vesentlig ved behandling av depresjon. Det overordnede budskapet er at placeboresponsen er større enn de fleste klinikere er klar over, men at den ikke utnyttes optimalt. Derved maksimeres ikke den kliniske nytten av «reell» behandling. De ni kapitlene omhandler blant annet kontekstavhengige variasjoner i placeboresponsen, forskjellene mellom placebo og «ikkebehandling», forventning og klassisk betinging som underliggende mekanismer, og etiske grenseoppganger ved bruk av placebo i forskning og klinisk praksis.

Målgruppen er ikke beskrevet, men forfatteren skriver klart, poengtert og uten unødig bruk av fagterminologi, slik at innholdet bør være lett tilgjengelig også for andre enn helsepersonell. Boken preges imidlertid av forfatterens psykiatriske bakgrunn. Blant annet er et helt kapittel viet drøfting av hvorvidt effekten av forskjellige former for psykoterapi bunner i et knippe av felles uspesifikke, placeboliknende faktorer, mer enn behandlingens spesifikke innhold. For terapeuter overbevist om «sin» spesifikke behandlingsforms overlegenhet vil dette kapitlet kunne bidra til en viss faglig ydmykhet.

Dette er en god oversikt over generelle problemstillinger knyttet til placeboeffekten. Forfatteren presenterer også noen gode, om enn velkjente, råd om hvordan placeboresponsen kan utnyttes bedre i den kliniske hverdagen. Ikke minst allmennpraktikere vil ha nytte av å bli påmint om at ti minutters konsultasjoner og elektroniske resepter gir dårlig grobunn for placeboeffekten. I ett av kapitlene tar han for seg etiske dilemmaer ved klinisk bruk av placebo, og gir flere forslag til hvordan man kan utnytte placeboeffekten uten å føre pasienten bak lyset. At placebo kan gi en god og vedvarende klinisk effekt også når den gis åpent, er overraskende, men kanskje ikke særlig anvendbart i norsk klinisk praksis.

For kolleger som primært arbeider med somatiske problemstillinger, vil boken neppe være et førstevalg, idet placeboresponsen ved slike tilstander er nokså stemoderlig behandlet. En del «friske» påstander om placeboeffekten ved lidelser som artrose, Parkinsons sykdom og allergi er ikke underbygd med litteraturreferanser, dette i motsetning til studier som omhandler psykiske lidelser.

Tross slike innvendinger grep jeg meg selv $i$ å hygge meg med denne lille boken og ta del i en erfaren klinikers kloke betraktninger. Som en appetittvekker for mer inngående fordypning i placeboresponsens fascinerende verden, kan jeg anbefale den.

Robin Holtedahl

Dr. Holtedahls spesialistpraksis

Oslo

\section{Tårenes mysterier}

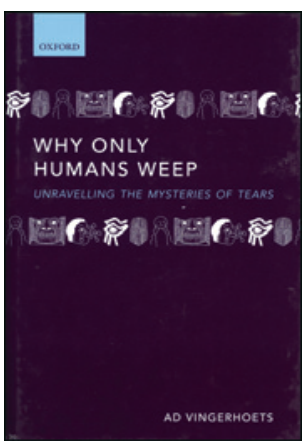

Ad Vingerhoets

Why only humans weep

Unravelling the mysteries of tears. 291 s, tab, ill. Oxford: Oxford University Press, 2013.

Pris GBP 35

ISBN 978-0-19-857024-0

Forfatteren pløyer både dypt og bredt i søken etter å belyse alle aspekter rundt gråt og gråterelatert atferd. Tittelen - Why only humans weep - sikter til det evolusjonsbiologiske mysteriet at det kun er hos mennesket man finner gråt i betydningen emosjonelle tårer. Som utgangspunkt vises til Charles Darwins omtale av gråt som en «meningsløs sekresjon av tårer», og boken kan ses som et forsøk på å forklare dette mysteriet Darwin ikke fant svar på.

Temaet har en bred tilnærming via evolusjonsbiologi, nevrofysiologi og atferdspsykologi. Videre diskuteres fenomenet gråt i historisk, religiøs, kulturell og antropologisk sammenheng. Forfatteren er psykolog og viser delvis til egen forskning, blant annet en studie av forekomst av gråt hos voksne og hvilke situasjoner som utløser gråt i ulike sosiale settinger.

Boken består av 13 kapitler. Innledningsvis beskriver forfatteren ulike teorier for hvilken funksjon emosjonelle tårer har hos mennesker. Gråt beskrives som en måte for individet å mestre følelser som er vanskelig å kommunisere verbalt. Gråt og gråterelatert atferd eksponerer individets sårbarhet og er et tydelig signal til omverdenen som typisk induserer empati og støtte, men reaksjonen på gråt kan variere avhengig av i hvilken situasjon man befinner seg i.

Kun 17 av de 291 sidene er viet til kapitlet om biologiske aspekter ved gråt og tåresekresjon. I dette kapitlet beskriver forfatteren relativt kortfattet hvilke strukturer i hjernen som er involvert i oppfattelsen av følelser og stressreaksjoner. Prinsippene rundt basal tåreproduksjon, reflekstårer og irritanter er greit forklart med en tilhørende skisse av tårekjertel og tåreveier. Selv om teksten på noen områder kan virke populærvitenskapelig, er innholdet grundig og med fyldig referanseliste. Illustrasjoner, bilder og skjematiske tegninger er fine. Et absolutt pluss er et rikt antall faktabokser med bakgrunnsstoff og kuriøse forklaringer, for eksempel Opprinnelsen til begrepet krokodilletårer, Løktårer, Hvordan håndtere babygråt, Førvitenskapelige teorier om tårenes opprinnelse og Empati og relaterte konsepter.

Forfatteren synes å ha lykkes med sitt ambisiøse prosjekt om å beskrive mysteriet gråt og tårer bredest mulig. Det er kanskje også den største svakheten, da temaet i seg selv er snevert, og boken kan kanskje virke noe monoton og nitidig. Likevel kan den appellere til mange faggrupper, og forfatteren angir selv psykologer, biologer, antropologer og psykiatere som målgruppe. Alle med noe interesse for gråt vil kunne finne mye å glede og undre seg over. Takket være den oversiktlige oppbyggingen kan leseren lett finne frem til de temaene som er av interesse.

Nina Krøll Angelsen

$\emptyset$ yeavdelingen

Universitetssykehuset Nord-Norge 